\title{
THE ATONEMENT PAGES
}

by

Anibal Bullon Hermoza

Bachelor of Industrial Engineering, Pontifical Catholic University of Peru, 1996

\author{
A Major Research Project \\ presented to Ryerson University \\ in partial fulfillment of the requirements for the degree of \\ Master of Digital Media \\ in the program of Digital Media \\ Toronto, Ontario, Canada, 2018
}

(C) Anibal Bullon Hermoza, 2018 


\section{AUTHOR'S DECLARATION FOR ELECTRONIC SUBMISSION OF A MRP}

I hereby declare that I am the sole author of this MRP. This is a true copy of the MRP, including any required final revisions.

I authorize Ryerson University to lend this MRP to other institutions or individuals for the purpose of scholarly research.

I further authorize Ryerson University to reproduce this MRP by photocopying or by other means, in total or in part, at the request of other institutions or individuals for the purpose of scholarly research.

I understand that my MRP may be made electronically available to the public. 


\title{
THE ATONEMENT PAGES
}

\author{
Anibal Bullon Hermoza \\ Master of Digital Media, 2018 \\ Yeates School of Graduate Studies \\ Ryerson University
}

\begin{abstract}
This paper examines the process of atonement beyond its religious significance as a powerful tool to rewire our brain, reconsider our old beliefs and establish new patterns of behaviors to improve our daily lives, repair relationships and live in harmony with ourselves and others. The work in this paper is based on self-exploration as well as a dive into the relevant scholarship with the overall goal of finding and sharing tools; and building road maps to help others heal themselves as well as relationships with others. The project relies primarily on personal exploration and a broad social media platform like Facebook to provide access to many others who can benefit from engaging with the topic and process of atonement.
\end{abstract}




\section{Acknowledgements}

I want to thank Ryerson University for becoming my Alma Mater in Canada, not only have they provided me with the necessary knowledge to update my skills but the right tools and people to finish successfully this adventurous journey.

There are four people I want to mention as the key elements toward finishing this journey; my supervisor, Alex Ferworn; the Associate Dean of Yeates School of Graduate Studies, Samantha Wehbi; Am Sagarwala and Mary Neelands. 


\section{Dedication}

I want to dedicate this project especially to my mother Ruth and my sister Jessica who have been great inspiration to work on this research.

Also, I want to mention my peers of the Master of Digital Media cohort 2016-2017 who have been great source of strength, love and compassion.

This has been a very important work for me not only academically, it has established a strong powerful structure to look at life differently and keep a non-judgement perspective towards people. In that effect, I want to dedicate this project to everyone that my actions have impacted consciously or unconsciously in the past. 


\section{Table of Contents}

$\begin{array}{ll}\text { 1. Introduction } & 1\end{array}$

2. A Life Journey toward Atonement $\quad 2$

2.1. The A-ha or A-duh moment $\quad 8$

2.2. A confused mind looking for some guidance $\quad 9$

2.3. Atonement, first researching results 10

2.4. A Jesuit Priest, return to the roots: The experience in Lima 12

2.5. Jordan Peterson, Osho, Sadguhru: The experience in Toronto 14

2.6. Family Reunion, the big opportunity for Forgiveness 15

$\begin{array}{lr}\text { 3. Conclusion } & 18\end{array}$

$\begin{array}{ll}\text { References } & 21\end{array}$ 


\section{Introduction}

The cycle of regret, grief, atonement and eventually forgiveness is a central theme for most of humanity. In a very personal journey through these cycles, either alone or with your loved ones, some part of this cycle touches all of us. In my case, as with many, I came through the experience through loss and eventually gaining a new insight into my own life and those that I love.

Atonement is recognized in all religions and in the field of Human Development as one of the most challenging journeys for an individual's personal development and growth.

Atonement is the practice of recognizing the impact your behavior has had on other people. It is personal accountability taken into action by going back to the people you have impacted and acknowledging any harm your actions have had on them. The critical step after the accountability of that harm is expressing a sincere apology for those actions and sincere regret.

The Atonement pages I created on Facebook strive to be an antidote or the counterpart to a series of hostile and negative messages that were posted in Facebook in a moment of extreme psychological pain and stress in my own life.

In the context of my project, It is not relevant if you are a religious or belong to any spiritual practice. If we understand that there is a more powerful force beyond ourselves, call it God, Universe, Love, etc. atonement can turn into a very powerful personal growth tool to help us not only to find peace but live a happier and more fulfilled life. 


\section{A Life Journey toward Atonement}

The experience of atonement has become the missing part of the whole equation of my life. Since I was introduced to the topic as part of my research project, I have started to notice many of the behaviors that I had never questioned and that might have led to many of the mistakes I have made during my life. It is an ongoing process, once initiated it can develop in many different ways in each of us.

All of the changes I have experienced seem so miraculous that even for myself it is hard to believe how a simple act of introspection and acceptance could open a myriad of possibilities, bring hope and vitality. Definitely some commitment on our side is one of the keys for a change of perspective and belief.

I once heard that most people older than 25 , can only change through severe trauma and that might be the reason why I was able to submerge myself into this difficult process linked to spirituality.

I will explain my experience of atonement that started in March 2018, but first I will mention some moments that precede the acceptance of atonement.

Two main events have been my biggest traumas in the last 5 years. In April 2013, my father's death got me stuck in a timeless world of sorrow, guilt and regret. In August 2017, in a manic episode, I almost hurt my mother accidentally.

This second event prepared me for what would be a great process of healing and rewiring of the brain, my experience of atonement. 
My father's death transformed my life. I now understand that, in a way, I died with him and entered into a transitional world I unconsciously created which I turned into my "Hell on Earth". In the process of helping my father with his transition, a new relationship was established between us, we became very good friends. This was a beautiful closure but during his sickness, fear took over and what could have been used as a natural way for healing ended up transforming into a long and very painful grieving time. I focused more in what I lost by ignoring him while he was alive more than what I gained during those six months of being very close to him. The feeling of guilt was the most corrosive feeling that transformed me into a sad and bitter person.

Life became harder after the first year. Desperation was the logical consequence of that guilt, at the same time there was a need to look for the perpetrators of my disgrace, I became obsessed with knowing who I was which turned into a race to know everything possible about my ancestors, my roots, the meaning of my eventual death and the reason I was the way I was. The only problem here was not having the right support to accompany that quest and increasingly becoming disconnected from my daily life. I didn't know I was already dealing with a severe depression.

After the second year things only worsened, keeping myself isolated and believing that many of my friends in Toronto were unfair and negligent towards me only added to negative feelings of resentment. I got to a very dangerous point for the first time in my life, thoughts of killing myself started to pollute my sick and tired mind. I immediately asked my mother to help me return and find refuge back in Lima, Peru.

During this time of recovery I realized I needed to look for a new interest or activity to bring some renewed breath to my life and studying was the best option. It was in August 2015 
when the Master of Digital Media (MDM) was presented to me accidentally while I was searching the Internet. I attended the poster presentation and got very excited to know more about the program and apply for the following year.

Some joy and excitement came back to me upon being accepted into the MDM, I thought this would be my return to the reality I had left while grieving. In September 2016 a new chapter opened in my life bringing a lot of anxiety and happiness at the same time. Things were difficult but the connection I created with the other students was more than enough to get through the difficulties. My ability to communicate had been affected and I felt I was re-learning my social skills. I fell in love with my peers, teachers and program but I set way too high expectations on all of them. I think I wanted to cover with them some of the emotional needs I was not aware of. I was definitely stuck in the victim mentality.

The first two semesters were a great experience of living, I made great friends. I had not only love but admiration for each of the people of my group. They taught me a whole new world, they took me for an artistic journey and they not only shared their love and skills but their trust and respect. I felt very inspired but again very fearful of not being at the same level of the program presenting my weird ideas at any opportunity and in assignments. The fields of neuroscience, brain development, consciousness and spirituality had gained my total attention during those previous difficult years.

The time for choosing the thesis arrived and I was not very clear with my ideas, I even chose a topic of my interest and my supervisor at that time was so engaged and supportive that he proposed I utilize a tool that was already in the market for the purposes of my thesis. That was absolutely amazing and perfect. 
This was when my mind started to get stuck with the anxiety concerning succeeding. Finishing the thesis was the ultimate goal, the last chance to show I could be of value for others, especially for my family (that is what I thought at that time). My mother was supposed to arrive for my thesis presentation in August 2017 and the pressure was increasing greatly without me noticing it.

On Jun 18, my laptop stopped functioning and the information for my thesis and all my research was not able to be recovered. I got into panic and became paralyzed, I engaged into a series of non-sense routines in a mental loop. This became a big breakdown that my brain simply couldn't handle.

I had the chance to see my peers after this but I really didn't ask for help. I was not ok because I started to lose weight dramatically and thoughts of failure and desperation were present on a daily basis. Not knowing what to do, and not being able to communicate to others, I started to victimize myself and Facebook was my way to cope with my situation. Not having the minimum tools to work on my project was the equivalent of failure. My mind was not able to produce solutions or even new creative ideas.

Fear again invaded me $100 \%$, the hatred towards myself came back and I started to project it onto others; family members, my peers and Ryerson University were the recipients of my poisoned heart and scared mind. Facebook was the mechanism I used to let people know what was happening to me and a way to blame them for me having reached that torturous point in my life. Now I can see how this was a bad way to ask for help; out of fear not out of love.

The worst happened close to my mother's arrival, my best friend from the program and another good friend of mine concerned about my deteriorating mental state showed up to take me to the emergency ward of a hospital but I couldn't allow myself to be taken into the hospital 
because my mother was supposed to arrive in less than a week, so I disregarded that as a priority. I went to pick up my mother at the airport thinking that her presence would be enough for me to get calm and in peace. It was not like that, my mother was now present and was trying to deal with my mental illness.

One day, I lost perspective, confronting my mother, I was close to harming her. That was it, my altered mind for two months combined with my lack of sleep, had me taking another wrong path where only medical intervention could help me to leave or escape.

I arrived at a very dangerous place where I was unconsciously trying to hurt myself, exposing myself to unnecessary danger but the worst and the most shocking event was this situation with my mother who I have always cherished and held in high regard. This would be the major event that would bring the acceptance of the concept of "atonement" with full force into the forefront of my life.

I was supposed to create an algorithm for Atonement but the more I tried to distill patterns, the more confused and complicated this topic became. As much as we defend our uniqueness the uniqueness of our paths get manifested in exactly the same way. There are no identical people like there are no identical paths. Our wisdom or common sense demands our full attention to learn from other's personal journeys and avoid unnecessary suffering.

The purpose of this project is to share a personal experience of atonement to leave some clues for others to apply this in their own process of personal and spiritual growth.

I have written about all the events that greatly affected me starting in April 2013 when my father passed away until August 2017 when I almost caused harm to my mother. It was a long time, a little more of 4 years crawling into a solitary world of personal punishment to compensate 
for the guilt when I lost my father. I gained a lot of personal development and improvements being at Ryerson University but I never thought that I needed any psychiatric treatment until this new breakdown.

It was clear to me that my mind had gotten into a broken and ill mind. It couldn't deal with a clear difficult moment of stress and It was like all the resentment got transformed into unlimited anger and anxiety.

Two weeks at a mental Hospital in September in Toronto were the beginning of the healing process. Psychiatric medication was prescribed to help me recover a daily pattern of sleep and some relief from anxiety.

I was not feeling safe in Toronto anymore and planned to go home to Peru by November 2017, bad memories and hidden remorse for all what I had done through my uncontrolled behavior started to haunt me.

Once at home, more peace and clarification started to come. Immediately upon my arrival to Lima, two of my closest friends noticed and let me know that I was talking with so much anger. It was very important to start to understand what happened to my mind because the feedback came from people I trust who knew me very well.

From November 2017 until March 2018, I had achieved a great physical and mental improvement but the uneasiness and burdensome thoughts not only continued but got worse. Since March 2018 to August 2018 there have been very distinguished periods of times that I can identify as my periods of Atonement. All what I have told so far can be considered as my Pre-Atonement stage. 
My Atonement journey has had at least 6 different periods until now:

\subsection{The A-ha or A-duh moment}

By March 2018 I was getting ready to go back to Toronto to continue with all that was left there. The first step was reconnecting with Ryerson University through the people who would make it possible to finish the MDM program. In a conversation with the person who would become my supervisor, atonement was suggested as the topic for my thesis project.

The big reasonable thought that invaded my mind was "Whatever I have done during those difficult months that my mind only wanted to forget must have been worse than what I am thinking it was. That's why the topic might have been suggested". I was very receptive to people suggestions or advice if they resonated strongly in me. My supervisor has a very sensitive fiber and I felt ready to follow that lead.

An impulse to go through what I wrote in the past followed this conversation and facing that shocking reality brought many of those memories and presented the horrible person I had become. It was the first time in seven months I had no other choice than having full acknowledgement of my actions. It was not easy to confront them, shame and pain were present and an instant desire to delete all those past Facebook posts as if with that action everything will become undone. Later, I would realize that only through atonement this could happen. This was only the first step.

Atonement would become the new focus without imagining that it would also be the clue which would allow me to untangle the knot of the suffering of my life. That's the reason I think Atonement has become the missing piece of the equation of my life and the right process to follow after my turbulent path in last 5 years. 


\subsection{A confused mind looking for some guidance}

Once I felt home and in a safe place on November 2017, I started to meet many people who were my closest friends from years ago and many others who were considered as mentors in the past. I think that I was desperately looking for wisdom and guidance, mainly from a male perspective. By March 2018 I had already listened to enough feedback that helped me to correct certain patterns of behavior. The time to come back to Toronto was getting close and I needed to feel ready to leave home in Lima, face all what I left behind and make Toronto my safe place again. I was feeling emotionally and physically stronger but some fear was still there. I knew returning wouldn't be easy.

The topic of atonement was a new fresh step for that guidance since it came from somebody who was a witness of all what happened during my mental illness. Automatically after hearing that word I went to Youtube and I found a six minute video from Marianne Williamson "Why does atonement matter?". That would take me to read her book "A Return to Love", based on the principles of another book "A course in Miracles". She defines "A course in Miracles" as a psychological mind training system to help you relinquish a thought system based on fear and replace it with a thought system based on love.

This perception was key for my engagement with the topic, atonement was not just a religious term but a concept that could help to train our minds and reprogram them with a new software based on love. Internally I felt a sense of finally being on track. A course in Miracles would give me the theoretical foundation to start to see things in a different way and apply atonement in a bigger perspective. 


\subsection{Atonement, first researching results}

Atonement is a central message in the Bible. God has provided atonement as a way for humankind to come back into harmonious relation with him. From the first stories in Genesis to the last visions of Revelation, God seeks to reconcile his people to himself.

Many religious faiths including Christianity refer to God as the creator. The fact that the concept of God is often referenced as love does not require belief, but it does require acceptance.

There is a central related message across all the major World faiths that God wants to share the beauty of existence with creatures and humans. Humans are often left with a unique role in those faiths. In Christianity for example, God has appointed humans as the crown of the species to oversee his good world under his care. One could easily question what have humans done with the place they were appointed as stewards, managers, overseers of God's good world through their choices, behaviors, introducing ruin, sometimes ruining themselves as well as ruining other people.

That's what the concept of human error or sin is all about, a human condition. Somehow, there is something forming inside us that gets magnified collectively. People can treat each other with contempt, inappropriately. They redefine right and wrong independent of a God and they don't want to submit to, so they end up with a World like ours.

What is God's response? What is God doing in the misguided manners most are participating? Atonement is one of the key words. So here is how being aware of our humanity and human error can be of such importance to build a better world not only for us but for the others around us. 
Because the Bible was written in Hebrew, Aramaic and Greek, Atonement might have a wider significance than the word in English.

"Atonement" = At-one-ment, to make right, to reconcile

The word in Greek is "hilasmos" and in Hebrew is "kipper".

It has 3 meanings:

1. To cover someone's failure

2. To erase the debt

3. To purify the relationship

People often think they are not deeply flawed humans, yet they keep acting out of the flaws. If they error, they have an advocate with the father, Jesus, his only son is the atoning sacrifice.

In the first letter of John, 1 John 1:5 - 2:2, this is mentioned 3 times:

$1: 7$ "the blood of Jesus purifies us from all sin"

1:9 "he will forgive us and purifies from all sin"

$2: 2$ "Jesus Christ is the atoning sacrifice for our sins"

The crucifixion didn't establish the atonement but the resurrection. The resurrection showed that nothing can destroy the truth and we all can overcome the cross. (Schucman, 2007).

If we choose atonement as a way of finishing the separation we have with God through the sin we are choosing pure love and that means a change of the way we think. Atonement is an act of courage, an act of faith. It is asking God to heal our minds. That's how we can reset our brains. (Schucman, 2007). 
Some of these main ideas come directly from "The Bible" and "A Course in Miracles". Those ideas were very important to consider atonement as a tool for my own healing.

\subsection{A Jesuit Priest, return to the roots: The experience in Lima}

It was very clear to me that the process of atonement was part of the training for the mind, but I wanted to get more information from a religious perspective. Since my elementary and high school was directed by Jesuits, I connected with the Jesuit University in Lima to have access not only to a Jesuit Priest but to the information their library could offer. Regardless of the clear separation and distance I established when I graduated at 17 , I had kept great respect and gratitude to those who taught me high values and critical independent thinking.

The Jesuit Priest, the Dean of the University met with me twice, the first meeting established rapport and created a good connection, it was like returning to my roots. I trusted the priest who recommended I read the passages of the resurrection of Christ and he lent me a book about San Ignacio de Loyola, the founder of Jesus Company.

The second meeting was actually the opportunity for me to start with the process of Atonement. After telling the Priest all what it was to create trouble for my disrupted peace, he suggested if I wanted to experience atonement in a personal way, he could see my remorse and real repent so he suggested to ask God directly to forgive my actions, and that would be enough to be forgiven. I received the Sacrament of Penitence after almost 30 years. The Father also suggested I go and receive the communion as the next step.

That's how my experience of atonement started, it was natural and not planned. I was ready to ask sincerely for forgiveness to a higher power. I needed to surrender to God, Love, Universe, etc to alleviate some of the spiritual burden. 
All of what I had done up to that moment took me only to bad decisions and terrible results so I had to accept I was lost and I was looking for some kind of guidance. This is exactly where Alcoholic Anonymous start their quest to recovery. Atonement only starts the end of the separation with God and others. This is the first step out of "The 12 Steps Program"

Accepting Jesus Christ as the atoning sacrifice means that we are able to undo our negative actions and this is not only hopeful but real great news. The truth can never be destroyed and that is what is shown with the resurrection, the triumph over death. So accepting atonement means allowing ourselves to go from the pain of the crucifiction to the liberation of the resurrection. The end of the separation and the beginning of our freedom. (Schucman, 2007).

Atonement is a change of perspective, a rewiring of the brain where we recognize our own divinity and understand that we need help to conduct ourselves in our spiritual journeys. We will make mistakes during this journey but we can minimize the impact or the pain. Pain is important for our journey to leave us lessons, suffering is not. Suffering is created by us because our perspective is being distorted and we have to find out where the problem is. Atonement takes us there. (Schucman, 2007).

\subsection{Jordan Peterson, Osho, Sadguhru: The experience in Toronto}

I initially took to the way Christians do atonement, through the sacrament of penitence and through a confessor since that was the faith I was raised in and it was a natural first step for me, but I believe that every person can get atonement applying his own wisdom or common 
sense. I was in a very crucial moment and the circumstances make it easier to receive this spiritual support. It worked for me, it doesn't have to work for others.

Once I arrived to Toronto, I contacted the closest Catholic communities to keep the spiritual support to take over with my responsibilities in Canada, I started to see atonement from a non-religious perspective. The book "12 Rules for Life, an antidote to chaos" by Jordan Peterson gave me a similar context from a more logical point of view and specific set of values instead of just following a role model like Christ based on faith. Jordan Peterson's perspectives on discipline, courage and the necessity of clear truthful thinking really inspired me.

During the last 3 months in Toronto, I decided to question my new principles reading and listening to Osho and Sadghuru. Jesuits taught me to always doubt anything and I want to keep an open perspective about atonement.

The Jewish tradition dedicates one day in the year for people to atone and forgive others, it is called "Yom Kippur Day". This has great power. So many people have such great difficulty admitting they were wrong or even when they recognize their errors taking the step to apologize to those they may have harmed can be very difficult out of fear and insecurity to name just a few of the obstacles. The longer they wait the more difficult it can become. Having a day like this in the Jewish tradition really does heal and renew relationships.

Before atonement was presented as the topic of my research, there was nothing that could alleviate the spiritual pain. When we act against others causing suffering or any harm we act against ourselves. That is what atonement has taught me, therefore, we must initiate a reconciliation with our own selves before trying to reconcile with others. I believe this has been the most important part of atonement in my journey up to date and it is an ongoing process. Just writing about this is making me realize that I have achieved great improvements and I will keep 
working my way to forgiveness. Atonement could be a long process depending on how committed you are to follow God's guidance or whoever you decide as your role model or spiritual guidance.

\subsection{Family Reunion, the big opportunity for Forgiveness}

After knowing that my actions could be forgiven through the acknowledgment of my past actions and the repercussions of them, showing real repent I was able to start to forgive myself. I know God had forgiven me already, my mother and sisters have done that as well but it was very important for me to feel I deserve that forgiveness. This didn't interfere with my process of atonement and only allowed me to be very aware of my actions and setting up new higher spiritual goals.

The process of atonement can take a long time because it is like rebuilding our life day by day. We go through our life, actions, memories and habits questioning everything, nothing can be taken for granted anymore. It's a reset of our brains, rewiring or the installation of a new software. We decide how deep you want to go, the deeper we go only will bring maximum joy and satisfaction. We can also make of the process of atonement a permanent habit to improve our lives and the relationship with others.

After five months of having atonement as my focus I was able to improve my mental health, understand the reasons for my past behaviors and acknowledge any harm I caused to others not only through my actions during last year but to many others in the past.

During the months of my severe mental illness the effect I had on my mother and closer family has been the most important reason to accept atonement in my life. After the acknowledgement of my actions and being forgiven by them, I had to make sure the conditions 
that took me to that dark hole wouldn't be able to repeat and that has been a very conscious process. Here lies your own pathway to apply atonement, how hard you want to be with yourself to make the adjustments, it's only you who will run the atonement and what the following steps will be.

My biggest commitment was to become a healthy person in the shortest time possible as a way to reconcile with my mother and family. In the process of achieving that, I have found that talking about my experience is just part of my atonement process. Writing about my experience has put pressure on accelerating the process but I certainly feel very happy because I can see the transformation and I have been getting ready to apologize to others I have harmed in the past. I have taken atonement as a spiritual tool to help me to change the habits that were interfering with finding my purpose and with the change of beliefs and paradigms. Life has been unfolding with a series of events I can perceive as miracles in my life.

One of those miracles, just happened 2 weeks ago. I had the great opportunity to meet with my mother and 3 sisters all together for the first time in 20 years and I have had the chance to prepare for this moment for almost 3 months working in this research in Toronto. My desire to be in front of them with so much calm and peace and apologize to them was really very encouraging. It was my first big attempt to reach the people I affected greatly last year.

What happened with my mother was really very traumatic and it was wrapped with so much guilt but now I see it as the triumph of pure love over fear. Atonement has really changed my perspective focusing on the triumph of God over death with the resurrection, instead of focusing in the suffering of Christ in the cross.

The opportunity to see my mother happy and at peace with her children lovingly unified was everything not only to feel their all their forgiveness but to understand what others might 
have felt with my actions. It was the first time I didn't need to think about it. I just felt it because I was able to see what my mother and sisters went through because of my actions during those three months last year. I understood that what I did to others was exactly the same as what I did to my mother and were equally harmful in various ways. I can try to imagine what others might have felt and I think that The Atonement Pages, the Digital Media Project will conclude my process of atonement to apologize to all the people I have affected in my life, especially my peers and people from Ryerson who were unfairly harmed by me. I have been so grateful for the grace of others and opportunity to grow and heal not only personally but help create tools and road maps that might help others heal themselves as well as relationships with others through atonement.

\section{Conclusion}

The Atonement Pages were created as a resource and source of inspiration to help heal relationships with ourselves and others. A way to experience a spiritual exercise that can produce many positive changes in the mental, physical and one's entire well being. The word Atone literally means "at-one", in harmony with oneself.

As a person who was dealing with a severe depression, I was immersed in destructive habits that became a normal way of living without noticing how much my life patterns were affecting others around me, especially my loved ones. The difficult road to healing myself and my relationships with others served as inspiration for the atonement pages. 
The Atonement pages strive to be an antidote or the counterpart to a series of hostile and negative messages that were posted in Facebook in a moment of extreme psychological pain and stress.

Just understanding the beauty and the dimensions of this word is enough to dedicate an entire page with that name. Atonement can relate strongly to a spiritual term but it is very practical in real life and in our daily activities. It helps us to see beyond the simple picture is in front of us. It goes deeper into the way we humans relate to each other and how harmonious we want our lives to be with the world and others.

It is really understanding that we are human beings so capable to love and do good to others as much as we can hate and do much harm. This is the acknowledgement that allows us to transcend and turn our weakness into a powerful tool to live our lives powerfully.

I have been exploring the word atonement from different perspectives, starting with the spiritual one for almost five months. Recognizing that Jesus already covered my mistakes with his life was a great starting point that allowed me to focus on things I needed to change.

This doesn't have to be the starting point for others. Accepting the consequences of what I created was the second big moment of relief. Because after admitting your mistakes the opportunity to fix or improve a situation opens.

After five months of atonement I can stop for a moment and see all the progress I have gained and I feel in a state of peace to ask publicly for forgiveness to each of the people I may have harmed because my negative actions that may have caused hurt to anyone. I recognize myself like a part of a great and unified body that have been caused sickness and suffering to others. As we all have heard about the butterfly effect I am certain that my actions have had terrible consequences, The body can't work perfectly fine if some parts are not working efficiently. There are many people I couldn't be happier to look for and ask personally for 
forgiveness but I have also accepted that keeping my distance could be better for some of them. This is not a quest to convince people of my sincere repentance, it is just a testimony that a lost human being still can be rescued with love.

I don't know how you might take my idea of atone, I just simply want others to know how much I regret all what I wrote in Facebook in the past to hit others with my sadness and misaligned and lost heart. I think I have had enough time to do a real brain reset. Having better mental health has helped greatly to any possible transformation.

I have had the chance to apologize to my family two weeks ago in person after almost one year after my biggest mental distress and it has been such a great experience of healing. Through them I was able to see all the others I affected and their forgiveness has been like a new breath of fresh air I am able to receive peace now with the feeling of moving from that breaking point to some joy and calm.

I am creating this interactive Facebook group to leave a voice of change and testament to inner transformation that I want to keep growing with all your support. I don't want anybody to feel alone or isolated in any way to get stuck in negative patterns without being able to have tools and support to escape all of that. I really hope others might benefit from my experience and we all together find new ways to reconcile with ourselves and others through the "language of atonement". 


\section{References}

Shucman, H. (2007). A course in miracles: Combined volume. Mill Valley, CA: Foundation for Inner Peace.

Williamson, M. (1992). A Return to Love. New York, NY: St. Martins Paperbacks.

Peterson, J. B. (2019). 12 RULES FOR LIFE: An antidote to chaos. S.I.: PENGUIN BOOKS.

Vasudev, J. (2016). Inner engineering: A Yogis guide to joy. New York: Spiegel \& Grau.

Osho. (2011). LIVING DANGEROUSLY. S.I.: GREEN BOOKS PUBLISHER.

Brooks, R. L. (2006). Atonement and forgiveness: A new model for Black reparations. Berkeley, CA: University of California Press.

Peterson, J. (Director). (n.d.). Reality and the Sacred[Video file]. Retrieved from https://youtu.be/2c3m0tt5KcE

Williamson, M. (Director). (n.d.). Why does atonement matter?[Video file]. Retrieved from https://youtu.be/xrTPTLeLA1M

Williamson, M. (Director). (n.d.). Atonement and Forgiveness[Video file]. Retrieved from https://youtu.be/T8n7wa aeho

Mackie, T. (Director). (n.d.). Atonement: The language of Faith[Video file]. Retrieved from https://youtu.be/SIxp_-4WuaQ

Peterson, J. (Director). (n.d.). Mysticism, Spirit and the Shadow[Video file]. Retrieved from https://youtu.be/zAsR6DZTvS8

The importance of Atonement[Video file]. (n.d.). Retrieved from https://youtu.be/z3Nj6jEIFmY

Sacrifice and Atonement[Video file]. (n.d.). Retrieved from https://youtu.be/G OIRWGLdnw 